\title{
Assessment of the healing of standardized wounds in rabbits treated serially with autologous platelet-rich plasma gel
}

\section{Avaliação da reparação de feridas padronizadas em coelhos tratadas de forma seriada com plasma rico em plaquetas autólogo gel}

\author{
Eliane Szücs dos Santos ${ }^{1}$; Cecília Braga Laposy ${ }^{2 *}$; Karina Gomes Barros Abegão ${ }^{1}$; \\ Rosa Maria Barilli Nogueira²; Gisele Alborghetti Nai²; Bruno Nascimento Bracale; \\ Inara Guastin Delfim ${ }^{3}$
}

\begin{abstract}
Recent studies have been carried out to evaluate the role of platelet-rich plasma (PRP) in the cicatrization of wounds; however, the protocols for treatment have been based on a single application of PRP.To evaluate the effect of autologous platelet-rich plasma in gel form on the cicatrization of cutaneous wounds in vivo experimental model, wounds were induced in the dorsal areas of six New Zealand white rabbits with the aid of an 8-mm punch. The right side was used as a control (A) and treated with $0.9 \% \mathrm{NaCl}$, whereas the left side (B) was treated serially with the autologous platelet-rich plasma gel. Lesions were assessed over a 17-day period. At days 0,10 and 17, the animals were evaluated and morphological and morphometric analyses of the wounds were performed. At day 17, a biopsy was performed for histopathological evaluation. Macroscopically, wounds treated with PRP showed better cicatrization and higher contraction percentages than the control wounds. Regarding the percentage of wound contraction, it was found that the average treated wound with autologous platelet-rich plasma gelwas $95 \%$ while withthecontrolwas $88 \%$. We concluded that autologous platelet-rich plasma gel is effective and accelerates cicatrization when used serially in short intervals, thus confirming its therapeutic potential in cutaneous lesions and potential as an alternative wound treatment option.
\end{abstract}

Key words: Autologous platelet-rich plasma. Rabbit. Skin regeneration. Wounds.

\section{Resumo}

Estudos recentes demonstram uma evolução do papel do plasma rico em plaquetas (PRP) na cicatrização de feridas. No entanto, os protocolos para tratamento baseiam-se em uma única aplicação do PRP. Para avaliar o efeito da aplicação seriada do plasma rico em plaquetas autólogo na forma gel sobre a cicatrização de feridas cutâneas em modelos experimentais in vivo, induziu-se feridas no dorso de seis coelhos brancos da raça Nova Zelândia com auxílio de um punch de $8 \mathrm{~mm}$. O lado direito foi considerado controle (A) e tratado com $\mathrm{NaCl} 0,9 \%$ e o lado esquerdo (B)e tratado com gel autólogo de plasma rico em plaquetas. As lesões foram avaliadas por um período de 17 dias. Nos dias 0,10 e 17, as feridas foram avaliadas morfológica e morfometricamente. No $17^{\circ}$ dia foi feita biópsia para avaliação histopatológica. Macroscopicamente, as feridas tratadas com PRP evidenciaram melhor cicatrização e

\footnotetext{
${ }^{1}$ Discentes do Programa de Pós-Graduação em Ciência Animal, Universidade do Oeste Paulista, UNOESTE, Presidente Prudente, SP, Brasil. E-mail: eliane@unoeste.br; ka.gomes_pp@hotmail.com

2 Prof ${ }^{\text {as }}$, Programa de Pós-Graduação em Ciência Animal, UNOESTE, Presidente Prudente, SP, Brasil. E-mail: claposy@unoeste. br; rosa@unoeste.br; patologia@unoeste.br

${ }^{3}$ Discentes do Curso de Medicina Veterinária, UNOESTE, Presidente Prudente, SP, Brasil. E-mail: brunovet@gmail.com; inara_ pp@hotmail.com

* Author for correspondence
} 
maior porcentagem de contração quando comparadas as feridas controle. Com relação ao percentual de contração das feridas, verificou-se que a média das feridas tratadas com plasma rico em plaquetas autólogo gel foi de $95 \%$, enquanto o lado controle foi de $88 \%$. Concluiu-se que o PRP autólogo gel é eficaz e acelera o processo de cicatrização, quando aplicado em intervalos curtos e de forma seriada, comprovando seu potencial terapêutico sobre lesões cutâneas, podendo ainda ser uma alternativa de tratamento de feridas.

Palavras-chave: Cicatrização. Coelhos. Feridas. Plasma rico em plaquetas autólogo.

\section{Introduction}

The cicatrization process involves a series of molecular and cellular events that interact to restore damaged tissue via mechanisms ranging from plasma extravasation, with coagulation and platelet aggregation, to re-epithelialization and damaged tissue remodelling with the aim of re-establishing tissue function (MENDONÇA; COUTINHONETTO, 2009).

Platelet-rich plasma (PRP) is considered advanced wound therapy for chronic and acute wounds. Autologous PRP gel consists on a source of growth factors that can be obtained through the isolation and concentration of platelets by using density gradient centrifugation. During platelet gel production, the venous blood is centrifuged to obtain a high platelet density (up to 6 times the initial concentration) in a small plasma volume. Platelet activation is performed by adding thrombin and calcium, thus initiating coagulation, which forms a gel enriched with platelet-derived growth factor, transforming growth factor- $\beta$, epidermal growth factor, and vascular endothelial growth factor (KON et al., 2011; MARX, 2004).

PRP is currently used in the treatment of chronic tendinopathies (KAUX; CRIELAARD, 2013), burns (CHEN; ZHENG, 2012), extremity wounds in patients with diabetes (SHAN et al., 2013), and radiotherapy-associated dermatitis (IERVOLINO et al., 2013) as well as in plastic surgery and dental implantation procedures (GONZÁLEZ et al., 2012). Therefore, the purpose of this study was to evaluate and compare the repair patterns of surgical wounds in healthy rabbits that were treated more than once a week with autologous gel-form PRP.

\section{Materials and Methods}

\section{Animals}

The animal ethics committee (protocol number 1183) of the University of Oeste Paulista, Presidente Prudente, Brazil, in accordance with the Institucional and Nacional guidelines approved this work. Six clinically healthy adult New Zealand white rabbits ( 3 males, 3 females; average weight, $3.0 \pm 1.0$ $\mathrm{kg}$ ) were used. The animals were maintained in individual cages at a room temperature of $22 \pm 2{ }^{\circ} \mathrm{C}$ and controlled photoperiods (12 hours light/dark); they were fed with commercial pellets and water $a d$ libitum.

\section{Collection and processing of autologous PRP gel}

Following anaesthesia, $4 \mathrm{~mL}$ of blood was collected from the central ear artery with a $25 \mathrm{G}$ surgical scalp vein needle. The collected sample was transferred to a tube containing the anticoagulant sodium citrate, and an aliquot was collected for automatic platelet counting (SysmexPoch Diff 100iV HematologyAnalyzer, Roche ${ }^{\circledR}$, São Paulo, SP). The blood was then centrifuged first at 200 $\times G$ (Excelsa Baby 206R centrifuge, Fanem ${ }^{\circledR}$, São Paulo, SP) for $10 \mathrm{~min}$ to form two fractions. The entire plasma fraction plus $200 \mu \mathrm{L}$ of the red fraction were transferred to a new tube and subjected to a second centrifugation at $400 \times G$ for 10 minutes (VENDRAMIN et al., 2010a).

At this stage, two distinct fractions were formed: the upper layer was slightly yellow and consisted of platelet-poor plasma; the lower layer was red. The platelet-poor plasma layer was removed and 
the platelets were counted again in the remaining fraction to determine if the final concentration was 6-times higher than the initial (STOCKHAM; SCOTT, 2008). Platelets were counted both automatically and manually (haemocytometer).

After confirming the adequate platelet concentration (up to 6 times the initial concentration), liquid PRP was transformed into a gel by adding $10 \%$ calcium gluconate to a final ratio of 4:1(OLIVEIRA-FILHO et al., 2008). The final PRP gel volume was approximately $0.5 \mathrm{~mL}$.

\section{Wound induction and treatment}

The rabbits were manually contained with a clipper (AGC2; Andis, $\mathrm{OH}$ ) for trichotomy of the right and left dorsal regions by using the number 40 blade. After this step, the animals were anaesthetized with a combination of tiletaminechlorohydrate and zolazepam (intramuscular injection of Zoletil ${ }^{\circledR} 50$, 15 mg/kg) (KANASHIRO; CASSU, 2008).

The skin was washed with $70 \%$ alcohol as an antiseptic and $1.0 \mathrm{~mL}$ of $2 \%$ lidocaine chlorohydrate with a vasoconstrictor was administered locally. An 8-mm punch was used to induce the surgical wounds in both the left (control) and right (treated with autologous PRP gel) dorsal regions, while the skin was carefully removed by using an anatomical tweezer to preserve the muscles. The control lesion (A, left side) was treated with a $0.9 \%$ sodium chloride solution, whereas the right side (B) was treated with autologous PRP gel. A sterile rayon swab $\left(1 \mathrm{~cm}^{2}\right)$ followed by an adhesive swab were then applied to both wounds. To avoid possible discomfort after surgery, animals were intramuscularly administered with tramadol chlorohydrate $(0.5 \mathrm{mg} / \mathrm{kg})$ every 12 hours for 3 consecutive days.

The autologous PRP gel was replaced every 3 days for a total of 5 replacements according to the pre-establish protocol with modifications (OLIVEIRA-FILHO et al., 2008). On day 17, a biopsy of the wound was taken by using an 8-mm punch and anatomical tweezers for histopathological evaluation of the lesions.

\section{Morphological and morphometric analyses}

On days 0,10 and 17, the borders of the wounds were measured (length and width) in millimetres by using a digital caliper (DC-60 Digimess ${ }^{\circledR}$, São Paulo, SP). Measurements were used to calculate the wound areas with the formula: $\mathrm{A}=\pi \times \mathrm{R} \times \mathrm{r}$, where $\mathrm{A}$ is the area, $\mathrm{R}$ is the longest radius, and $\mathrm{r}$ is the shortest radius (SCHIRATO et al., 2006).

The percentage of lesion contraction was calculated by using the mathematical model in which the percentage of contraction $(\mathrm{Pc})$ equals the final area (Af) minus the initial area (Ai) times $100(\times 100)$ divided by the initial area (Ai); the formula is $\mathrm{Pc}=(\mathrm{Af}-\mathrm{Ai}) \times 100 / \mathrm{Ai}($ OLIVEIRA et al., 2000; SCHIRATO et al., 2006). Wounds were photographed with a digital camera (Coolpix P510, Nikon $^{\circledR}$, Brazil).

\section{Histopathological analysis}

Before to fragment removal (day 17), the same anaesthesia protocol described above was performed. In the epidermis, degeneration, necrosis, and regeneration were evaluated, whereas in the dermis, the following aspects were evaluated: edema, haemorrhage, neovascularization extent, fibrosis degree, and inflammatory infiltrate type. For all parameters, the scoring system was: (0) absent, (1) slight alteration, (2) moderate alteration, and (3) accentuated alteration. Skin samples were fixed in $10 \%$ formalin solution for $24-48 \mathrm{~h}$ and then washed in running water for $1 \mathrm{~h}$. After that, the fragments were transferred to $70 \%$ alcohol and processed according to routine histology techniques. Paraffinembedded tissue sections (5um) were stained with haematoxylin and eosin (TOLOSA et al., 2003) and were evaluated with ordinary light microscopy. A board-certified pathologist reviewed all slides and was blinded to the groups (MORI et al., 2009). 


\section{Statistical analysis}

A paired $t$-test was used to compare the same variables between treated wounds and controls $(\mathrm{A} \times \mathrm{B})$. For the wound areas, repeated measures analysis of variance was performed with the Mauchlysphericity test validation and Sidak correction. For the histopathological analysis, the non-parametric Wilcoxon test was used between treated and controls lesions $(\mathrm{A} \times \mathrm{B})$. The SPSSprogram was used for all of the analyses with a significance level of $5 \%$.

\section{Results}

The wounds ( $\mathrm{A}$ and $\mathrm{B}$ ) remained pink throughout the entire experiment, and no macroscopic signs of contamination, excess granulation or exudate were noted.

Lesion sizes gradually decreased (Figure 1) in inverse proportion to the percentage of contraction $(P=0.01)$. Concerning the percentage of wound contraction, the average contraction of PRP-treated lesions was $95 \%$ (Table 1), whereas that of control lesions was $88 \%(P<0.05)$. Only one animal treated with the autologous gel demonstrated $100 \%$ cicatrization.

The histopathology findings revealed that, for animals treated with autologous PRP, 50\% (3 rabbits) had partial and 50\% (3 animals) had total reepithelisation. Of the animals with control wounds, $33.3 \%$ (2 animals) had partial and the other $66.7 \%$ (4 animals) had total re-epithelisation.
For both the treated and control wounds, the presence of a fibrin-leukocyte scar and the occurrence of neovascularization were observed (Figure 2) in $66.7 \%$ (4 rabbits) and absent in 33.3\% (2 rabbits). Statistically, the results were similar $(P=0.31)$.

Considering the inflammatory infiltrates, lymphocytes and a few macrophages with values $\geq$ $50 \%$ were detected in lesions A and B. Moderate levels of fibroblasts and collagen fibres $(\geq 65 \%)$ were seen in both $\mathrm{A}$ and $\mathrm{B}$ wounds, while high levels were seen in the remaining cases.

Figure 1. Evaluation of cicatrization on days 0, 10, and 17 highlighting the lesions' macroscopic characteristics. A, control side; B, treated side with autologous plateletrich plasma. Of note, the presence of a scar and wound reduction was more intense in wounds treated with the autologous platelet-rich plasma gel.

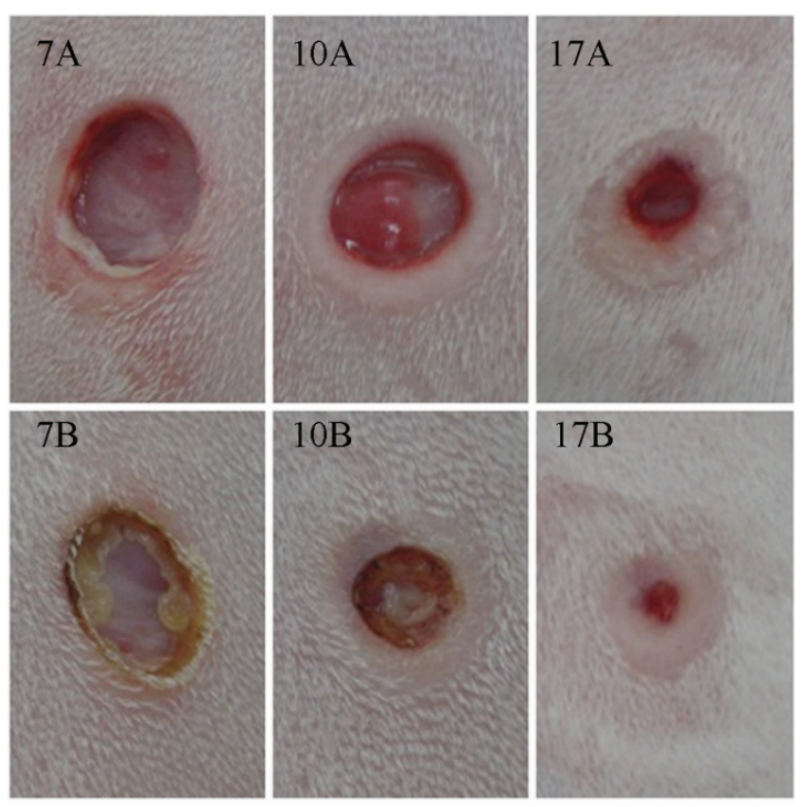

Table 1. Average values \pm standard deviations of the wound areas $\left(\mathrm{mm}^{2}\right)$ of the control (A) and autologous rabbit platelet-rich plasma-treated (B) lesions.

\begin{tabular}{cccc}
\hline Times/Wounds & A & B & P-value \\
\hline M0 & $82.89 \pm 13.21^{\mathrm{Aa}}$ & $84.97 \pm 12.94^{\mathrm{Aa}}$ & 0.34 \\
M10 & $66.78 \pm 20.39^{\mathrm{Ab}}$ & $43.53 \pm 20.46^{\mathrm{Bb}}$ & 0.04 \\
M17 & $8.03 \pm 5.16^{\mathrm{Ac}}$ & $3.63 \pm 2.63^{\mathrm{Bc}}$ & 0.02 \\
\hline
\end{tabular}

${ }^{\mathrm{AB}}$ Different upper-case letters in the same line: $P<0.05$

${ }^{a b}$ Lower-case letters in the same column: $P<0.05$ 
Figure 2. Photomicroscopy of the control wounds (A and $\mathrm{B})$ and treated wounds (C and D) on day 17. A, partial re-epithelialization and fibrin-leukocyte scar (haematoxylin-eosin staining; magnification, 100×); $\mathrm{B}$, moderate neovascularization and high numbers of fibroblasts (haematoxylin-eosin staining; magnification, $400 \times)$; C, total re-epithelialization and fibrin-leukocyte scar (haematoxylin-eosin staining; magnification, $100 \times)$; D, moderate neovascularization, high number of fibroblasts, and moderate inflammatory infiltrate (haematoxylin-eosin staining; magnification, 400×).
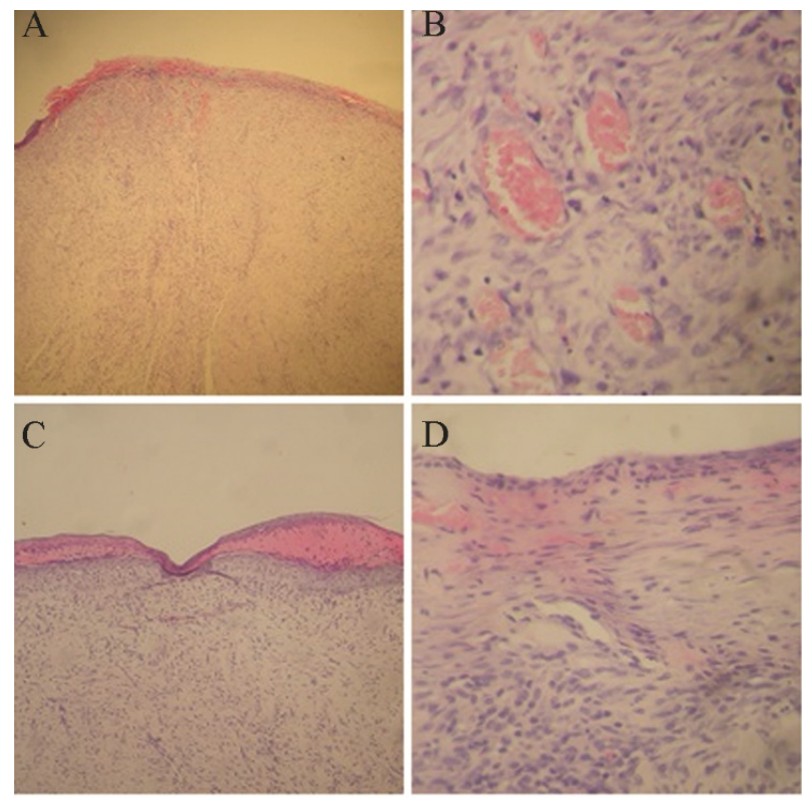

\section{Discussion}

Macroscopically, wounds treated with PRP showed better cicatrization and higher contraction percentages than the control wounds. The same results were previously reported for cutaneous grafts in cases of chronic wounds (VENDRAMIN et al., 2010a) and skin grafts in rabbits (VENDRAMIN et al., 2010b). These results highlight the activity of the cytokines and growth factors released by the platelets that contributed to accelerating the cicatrization process (MAIA; SOUZA, 2009).

When using PRP in standardized wounds in the dermis of rats, Bauer et al. (2009) did not observe accelerated cicatrization or contractions of the wound areas. One possible explanation for this was the fact that the gel was administered only once; other studies have suggested that the repetitive use of PRP is required for satisfactory results (KLAUMANN et al., 2008).

The fact that the PRP was of homologous origin could also explain the difference in results, as its use did not interfere with cicatrization; however, no toxic or adverse effects were observed (BAUER et al., 2009). In this study, the gel was administered in 3- or 4-day intervals. Patients with chronic ulcers and an aid in the management of acute trauma wounds, who were treated with weekly doses of PRP also showed greater repair areas (ANITUA et al., 2007; KAZAKOS et al., 2009), which emphasizes the importance of serial gel administration to accelerate the cicatrization process.

Histopathological analysis revealed moderate to high levels of fibroblasts and collagen fibres in the third week of cicatrization. When compared microscopically, the wound A and B findings showed that PRP was a determinant of wound remodelling by promoting fibroblast proliferation, collagen fibres, and neovascularization. These results corroborate the observations by Vendramin et al. (2010b), who showed that PRP is effective in the remodelling and cicatrization processes of the skin grafts in rabbits compared with nontreated animals. Other authors have also confirmed increased production rates of collagen fibres and fibroblast proliferation that accelerated the cicatrization process in humans (BANHOT; ALEX, 2002).

\section{Conclusion}

Further studies focusing on the efficacy of autologous PRP in cicatrization should be performed, as this method is a non-expensive and easily performed method with the potential to be used in several therapies. The use of autologous PRP gel in cutaneous wounds, serially and in short intervals, accelerates cicatrization, making it an alternative therapy for wound healing. 


\section{Acknowledgments}

We thank Professor Rogério Giuffrida for providing statistical consultation.

\section{References}

ANITUA, E.; AQUIRRE, J. J.; ALGORTA, J.; AYERDI, E.; CABEZAS, A. L.; ORIVE, G.; ANDIA, I. Effectiveness of autologous preparation rich in growth factors for the treatment of chronic cutaneous ulcers. Journal of Biomedical Materials Research. Part B, Applied Biomaterials, Hoboken, v. 84, n. 2, p. 415-420, 2007.

BANHOT, S.; ALEX, J. C. Current applications of platelet gels in facial plastic surgery. Facial Plastic Surgery, New York, v. 18, n. 1, p. 27-33, 2002.

BAUER, J. A.; CORREA, L.; LIMA, F. L. M.; LIMA, L. A. P. A.; PUSTIGLIONI, F. E. Efeitos do plasma rico em plaquetas no processo de reparação de feridas dérmicas padronizadas em ratos. Revista Periodontia, Belo Horizonte, v. 19, n. 3, p. 98-108, 2009.

CHEN, W.; ZHENG, J. S. Advance in the research of platelet-rich plasma in burn treatment. Zhonghua Shao Shang Za Zhi, Beijing, v. 28, n. 4, p. 288-290, 2012.

GONZÁLEZ, M.; ARTEAGA-VIZCAÍNO, M.; BENITO, M.; BENITO, M. Aplicación del plasma rico em plaquetas (PRP) y sus derivados em implantología dental y cirurgía plástica. Investigación Clinica, Maracaibo, v. 53, n. 4, p. 408-418, 2012.

IERVOLINO, V.; Di COSTANZO, G.; AZZARO, R.; DIODATO, A. M.; Di MACCHIA, C. A.; Di MEO, T.; PETRUZZIELLO, A.; LOQUERCIO, G.; MUTO, P.; APICE, G.; CACCIAPUOTI, C. Platelet gel in cutaneous radiation dermatitis. Support Care Cancer, Berlin, v. 21, n. 1, p. 287-293, 2013.

KANASHIRO, G. P.; CASSU, R. N. Anestesia em animais selvagens e de laboratório. In: ANDRADE, S. F. Manual de terapêutica veterinária. 3. ed. São Paulo: Roca, 2008. p. 728-745.

KAUX, J.; CRIELAARD, J. M. Platelet-rich plasma application in the management of chronic tendinopathies. Acta Orthopaedica Belgica, Bruxelles, v. 79, n. 1, p. 1015, 2013.

KAZAKOS, K.; LYRAS, D. N.; VERETTAS, D.; TILKERIDIS, K.; RYFONIDES, M. The use of autologousPRP gel plasma as an aid in the management of acute trauma wounds. Injury, Amsterdam, v. 40, n. 8, p. 801-805, 2009.
KLAUMANN, P. R.; WOUK, A. F. P. F.; SILAS, T. Patofisiologia da dor. Archives of Veterinary Science, Curitiba, v. 13, n. 1, p. 1-12, 2008.

KON, E.; FILARDO, G.; DI MARTINO, A.; MARCACCI, M. Platelet-rich plasma (PRP) to treat sports injuries: evidence to support its use. Knee Surgery, Sports Traumatololgy, Arthroscopy, Heidelberg, v. 19, n. 4, p. 516-527, 2011.

MAIA, L.; SOUZA, M. V. Componentes ricos em plaquetas na reparação de afecções tendo-ligamentosas e osteo-articulares em animais. Ciência Rural, Santa Maria, v. 39, n. 4, p. 1279-1286, 2009.

MARX, R. E. Platelet-rich plasma: evidence to support its use. Journal of Oral and Maxillofacial Surgery, Philadelphia, v. 62, n. 4, p. 489-496, 2004.

MENDONÇA, R. J.; COUTINHO-NETTO, J. Aspectos celulares da cicatrização de feridas. Anais Brasileiros de Dermatologia, Rio de Janeiro, v. 84, n. 3, p. 257-262, 2009.

MORI, G. G.; MORAES, I. G.; NUNES, D. C.; CASTILHO, L. R.; POI, W. R.; CAPALDI, M. L. P. M. Biocompatibility evaluation of alendronate paste in rat's subcutaneous tissue. Dental Traumatolology, Copenhagen, v. 25, n. 2, p. 209-212, 2009.

OLIVEIRA, S. T.; LEME, M. C.; PIPPI, N. L.; RAISER, A. G.; MANFRON, M. P. Formulações de confrey (Symphytum officinale L.) na cicatrização de feridas cutâneas em ratos. Revistada FZVA, Uruguaiana, v. 7/8, n. 1, p. $65-74,2000$.

OLIVEIRA-FILHO, M.A.; ALMEIDA, L. E.; PEREIRA, J. A.; NASSIF, P. A. N.; CZECZKO, N. G.; KUME, M. H.; SILVA, M. B. G. Plasma rico em plaquetas de coelhos: introdução a um modelo experimental. $A B C D$ : Arquivos Brasileiros de Cirurgia Digestiva, São Paulo, v. 21, n. 4, p. 175-179, 2008.

SCHIRATO, G. V.; MONTEIRO, F. M. F.; SILVA, F. O.; LIMA FILHO, J. L.; LEÃO, A. M. A. C.; PORTO, A. L. F. O polissacarídeo do Anacardium occidentale L. na fase inflamatória do processo cicatricial de lesões cutâneas. Ciência Rural, Santa Maria, v. 36, n. 1, p. 149-154, 2006.

SHAN, G. Q.; ZHANG, Y. N.; MA, J.; LI, Y. H.; ZUO, D. M.; QIU, J. L.; CHENG, B.; CHEN, Z. L. Evaluation of the effects of homologous platelet gel on healing lower extremity wounds in patients with diabetes. International Journal of Lower Extremity Wounds, Thousand Oaks, v. 12, n. 1, p. 22-29, 2013.

STOCKHA M, S. L.; SCOTT, M. A. Fundamentals of veterinary clinical pathology. Iowa: Blackwell, 2008. $908 \mathrm{p}$. 
TOLOSA, E. M. C.; RODRIGUES, C. J.; BEHMER, A. O.; FREITAS-NETO, A. Manual de técnicas para histologia normal e patológica. 2. ed. São Paulo: Manole, 2003. $341 \mathrm{p}$.

VENDRAMIN, F. S.; FRANCO, D.; FRANCO, T. R. Utilização do plasma rico em plaquetas autólogo nas cirurgias de enxertos cutâneos em feridas crônicas. Revista Brasileira de Cirurgia Plástica, São Paulo, v. 25, n. 4, p. 589-594, 2010a.
VENDRAMIN, F. S.; FRANCO, D.; SCHAMALL, R. F.; FRANCO, T. R. Utilização do plasma rico em plaquetas (PRP) autólogo em enxertos cutâneos em coelhos. Revista Brasileira de Cirurgia Plástica, São Paulo, v. 25, n. 1, p. 4-10, 2010 b. 
